\title{
Pengaruh Pemberian Pendidikan Kesehatan Dengan Metode Story Telling Terhadap Tingkat Pengetahuan Kebersihan Gigi Pada Anak Usia Sekolah di SDN Inpres Kala Tahun 2019
}

\author{
Arif Budiwibowo'), Sahriana2), Ayudiah Uprianingsih ${ }^{3)}$ \\ 1), 2), 3) STIKES YAHYA BIMA \\ Email : arif.budiwibowo@yahoo.co.id
}

\begin{abstract}
ABSTRAK : Kesehatan gigi dan mulut merupakan bagian dari kesehatan jasmani yang tidak dapat dipisahkan satu dan lainnya karena akan mempengaruhi tubuh secara keseluruhan. Kesehatan harus dimulai sejak dini, oleh karena itu perlu diberikan pendidikan kesehatan kepada anak mulai dari sekolah dasar untuk membangun rangsangan dan kesadaran anak tentang kebersihan dan pentingnya hidup sehat, salah satu diantaranya adalah kebersihan gigi. Penelitian ini bertujuan untuk mengetahui pengaruh pemberian pendidikan kesehatan dengan metode story telling terhadap tingkat Pengetahuan Kebersihan Gigi Anak Sekolah di SDN Inpres Kala Tahun 2019. Bentuk penelitian ini adalah penelitian eksperimen yang menggunakan one group pretest-posttest design. Data diperoleh menggunakan dua alat istrumen penelitian yaitu obsevasi dan test, kemudian dilakukan analisis menggunakan program komputer SPSS 16.0 for Windows. Sebelum mendapatkan pendidikan kesehatan melalui metode story telling, sebagian besar anak sekolah di SDN Inpres Kala memiliki tingkat pengetahuan kebersihan gigi kategori sedang. Setelah mendapatkan pendidikan kesehatan melalui metode story telling, sebagian besar anak sekolah di SDN Inpres Kala memiliki tingkat pengetahuan kebersihan gigi pada kategori tinggi ( $\mathrm{p}=$ $0,037 ; p<0,05)$. Sehingga terdapat pengaruh yang signifikan pendidikan kesehatan melalui metode story telling terhadap tingkat pengetahuan kebersihan gigi anak sekolah di SDN Inpres Kala
\end{abstract}

Kata kunci: Story telling, pengetahuan dan quasi experimen

\section{PENDAHULUAN}

Kesehatan gigi dan mulut merupakan bagian dari kesehatan jasmani yang tidak dapat dipisahkan satu dan lainnya karena akan mempengaruhi tubuh secara keseluruhan. Gigi dan mulut yang sehat, akan terhindar dari gangguan aktivitas seperti berbicara, makan, dan bersosialisasi karena terhindar dari rasa sakit, tidak nyaman, dan malu [1].

Salah satu penyakit yang sering muncul pada anak adalah karies gigi. Karies gigi merupakan permasalahan gigi yang sering timbul tidak hanya pada orang dewasa tetapi juga dialami oleh anak-anak. Oral hygiene yang buruk dapat menjadi salah satu faktor resiko terjadinya karies [2].

Berdasarkan data profil NTB 2017 jumlah pencabutan gigi meningkat dari $0,70 \%$ pada tahun 2016 menjadi 1,16\% pada tahun 2017 dibandingkan tumpatan gigi tetap, hanya Kabupaten Lombok Barat, Kota Mataram dan Kabupaten Bima yang tumpatan gigi tetap lebih besar dari pada pencabutan gigi tetap. Akan tetapi tumpatan gigi tetap juga dapat mempengaruhi kesehatan gigi. Hal tersebut dikarenakan sebagian besar masyarakat masih kurang memperhatikan kesehatan gigi dan mulut dan masih rendahnya promosi tentang kesehatan gigi dan mulut (Data NTB, 2017).

Data awal yang didapat pada tanggal 10 April 2019 di SDN INPRES Kala, dari jumlah keseluruhan siswa dari kelas I-VI adalah 60 orang, yang mengalami gigi berlubang sebanyak 13 orang dan karies gigi 20 orang, hal ini disebabkan karena kurangnya kesadaran tentang pentingnya kebersihan gigi, terlalu sering mengkonsumsi makanan yang manis dan lengket seperti coklat, permen dan biskuit.

Upaya yang dapat dilakukan untuk mengurangi kasus gangguan kesehatan gigi pada anak usia sekolah dapat dilakukan dengan cara pemberian pendidikan kesehatan menggunakan metode story telling (dongeng) atau dengan metode penyuluhan. Metode penyuluhan dapat digunakan sebagai alat, strategi, dan motivasi peserta didik agar dapat dengan cepat menerima informasi.

Dongeng adalah cerita fiktif sederhana yang tidak benar-benar terjadi yang berfungsi untuk mendidik juga menghibur [3]. Metode dongeng memiliki efek yang lebih signifikan dibandingkan dengan metode ceramah terhadap perubahan pengetahuan, sikap dan praktek dalam pendidikan kesehatan gigi dan mulut [4].

\section{METODE PENELITIAN}

Bentuk penelitian eksperimen yang digunakan dalam penelitian ini adalah one group pretest-posttest design karena penelitian ini tanpa menggunakan kelompok kontrol, sehingga satu kelompok tersebut mendapatkan pelatihan yang terencana, sehingga hasil yang diperoleh dapat maksimal, dengan menggunakan desain $\mathrm{O} 1 \mathrm{X} \mathrm{O}$. Pelaksanaan penelitian dengan desain ini dilakukan dengan memberikan perlakuan $(\mathrm{X})$ terhadap satu kelompok, yaitu kelompok eksperimen. Sebelum diberikan perlakuan, kelompok tersebut diberi pretes(O1), dan setelah diberikan perlakuan posttes (02). 
Hasil kedua tes itu dibandingkan, untuk menguji apakah perlakuan memberi pengaruh kepada kelompok tersebut.

Tabel 1. one group pretest-posttest design

\begin{tabular}{|l|l|l|}
\hline Pretest & Treatment & Posttest \\
\hline $\mathrm{O} 1$ & $\mathrm{X}$ & $\mathrm{O} 2$ \\
\hline
\end{tabular}

Keterangan :

O1 : Perilaku kebersihan gigi (sebelum diberikan perlakuan)

$\mathrm{X}$ : Tindakan atau perlakuan

O2 : Perubahan perilaku kebersihan gigi (setelah diberikan perlakuan)

\section{HASIL DAN PEMBAHASAN}

\section{Karakteristik responden}

Jumlah responden dalam penelitian ini berjumlah 37 orang anak sekolah yang mengalami karies gigi dan gigi berlubang yang berusia 9-12 tahun di SDN Inpres Kala tahun 2019. Karakteristik responden berdasarkan usia, jenis kelamin dan kelas.

Tabel 2. Karakteristik responden berdasarkan usia

\begin{tabular}{ccc}
\hline \multirow{2}{*}{ Usia } & \multicolumn{2}{c}{ Jumlah } \\
\cline { 2 - 3 } & $\mathbf{n}$ & $\mathbf{\%}$ \\
\hline 9 & 13 & $35,1 \%$ \\
10 & 6 & $16,2 \%$ \\
11 & 10 & $27,0 \%$ \\
12 & 8 & $21,6 \%$ \\
\hline Total & $\mathbf{3 7}$ & $\mathbf{1 0 0 \%}$ \\
\hline
\end{tabular}

Tabel tersebut menjelaskan bahwa usia 9-12 tahun di SDN Inpres Kala selama penelitian yang mengalami karies gigi dan gigi berlubang 13 responden $(35,1 \%)$ yang berusia 9 tahun, 6 orang responden $(16,2 \%)$ usia 10 tahun, 10 orang responden $(27,0 \%)$ usia 11 tahun dan 8 orang responden $(21,6 \%)$ berusia 12 tahun.

Tabel 3. Karakteristik responden berdasarkan Jenis Kelamin

\begin{tabular}{|c|c|c|}
\hline \multirow{2}{*}{ Jenis kelamin } & \multicolumn{2}{|r|}{ Jumlah } \\
\hline & $\mathbf{n}$ & $\%$ \\
\hline Laki-laki & 17 & $45,9 \%$ \\
\hline Perempuan & 20 & $54,1 \%$ \\
\hline Total & 37 & $100 \%$ \\
\hline
\end{tabular}

Karakteristik resonden berdasarkan Jenis Kelamin di SDN Inpres Kala selama penelitian yaitu laki-laki sebanyak 17 orang $(45,9 \%)$ dan perempuan sebanyak 20 orang $(54,1 \%)$.

Tabel 4. Karakteristik responden berdasarkan kelas

\begin{tabular}{lll}
\hline \multirow{2}{*}{ Kelas } & Jumlah & \\
\cline { 2 - 3 } & n & $\mathbf{1 0 0 \%}$ \\
\hline Kelas 3 & 9 & $24,3 \%$ \\
Kelas 4 & 10 & $27,0 \%$ \\
Kelas 5 & 10 & $27,0 \%$ \\
Kelas 6 & 8 & $21,6 \%$ \\
\hline Total & 37 & $100 \%$ \\
\hline
\end{tabular}

Berdasarkan tabel di atas terlihat bahwa karakteristik responden berdasarkan kelas adalah responden yang kelas 3 SD berjumlah 9 orang $(24,3 \%)$, kelas 4 SD berjumlah 10 orang $(27,0 \%)$ kelas 5 SD berjumlah 10 orang $(27,0 \%)$ dan kelas 6 SD berjumlah 8 orang $(21,6 \%)$

\section{Hasil Uji Statistik}

Tabel 5. hasil uji normalitas data pre-test

\begin{tabular}{|c|c|c|c|}
\hline Data & $\mathbf{n}$ & Signifikan (p) & Keterangan \\
\hline $\begin{array}{l}\text { Pre- } \\
\text { test }\end{array}$ & 37 & 0,069 & $\begin{array}{l}\text { Distribusi } \\
\text { normal }\end{array}$ \\
\hline $\begin{array}{l}\text { Post- } \\
\text { test }\end{array}$ & 37 & 0,018 & $\begin{array}{l}\text { Distribusi } \\
\text { tidak normal }\end{array}$ \\
\hline
\end{tabular}

Hasil uji normalitas data dengan tekhnik Shapiro-Wilk pada tabel menunjukan bahwa nilai signifikan (p) data pre-test menunjukan hasil diatas 0,05 dan sebaliknya data post-test menunjukan hasil signifikan dibawah 0,05 . Indikasi data distribusi normal adalah memiliki nilai signifikan (p) diatas 0,05 [5]. Jenis uji statistik yang digunakan dalam penelitian ini adalah uji statistik Wilcoxon signed ranks test yang termasuk dalam jenis statistik non parametrik [6].

Tabel 6. hasil uji wilcoxon signed ranks test data pretest

\begin{tabular}{llllll}
\hline & & $\mathrm{n}$ & Mean & Signifikan & Keterangan \\
\hline \multirow{4}{*}{ Ranks } & Posititif & 13 & 13,58 & & \\
& Negative & 21 & 19,93 & 0,037 & Ada \\
& & & & & perbedaan \\
& Ties & 3 & & & \\
Total & 37 & & & \\
\hline
\end{tabular}

Hasil uji wilcoxon signed ranks test pada tabel 5.5 menunjukan bahwa hasil uji menghasilkan nilai signifikan sebesar 0,037 . Nilai uji signifikan yang lebih kecil dari 0,05 mengindikasikan adanya perbedaan yang signifikan secara statistik.

\section{Pembahasan}

Berdasarkan hasil penelitian diperoleh data bahwa penelitian terhadap pengaruh pendidikan story telling terhadap tingkat pengetahuan kebersihan gigi ada perbedaan antara tingkat kebersihan gigi sebelum dan sesudah pemberian metode story telling. Terdapat pengaruh yang signifikan pemberian metode story telling terhadap tingkat pengetahuan kebersihan gigi dimana nilai $\mathbf{p}=\mathbf{0 , 0 3 7}$.

Sebelum diberikan perlakuan yang rutin menyikat gigi $2 \mathrm{x}$ sehari sebanyak 4 orang $(10,8 \%)$, yang tidak rutin menyikat gigi $2 \mathrm{x}$ sehari sebanyak 33 orang $(89,2 \%)$, jadi jumlah keseluruhan responden ada 37 orang $(100 \%)$, setelah mendapatkan perlakuan yang rutin menyikat gigi $2 \mathrm{x}$ sehari sebanyak 14 orang $(37,8 \%)$, yang tidak rutin menyikat gigi $2 \mathrm{x}$ sehari 
sebanyak 23 orang $(62,2 \%)$, jadi jumlah keseluruhan responden ada 37 orang (100\%). Penelitian ini sejalan dengan penelitian (Ibda, 2015) anak-anak yang duduk dikelas III SDN sudah memiliki perkembangan cukup baik dari segi intelektual, motorik, bahasa dan sosial, karena pada fase ini adalah fase yang cocok untuk dilatih keterampilan personal higyene, sehingga lebih mudah melatih anak menyikat gigi secara rutin minimal 2 kali sehari yaitu setelah makan pagi dan ketika akan tidur.

Hasil penelitian dapat dilihat bahwa ada pengaruh pendidikan kesehatan melalui metode story telling terhadap tingkat pengetahuan kebersihan gigi anak usia sekolah di SDN Inpres Kala. Hasil penelitian ini sejalan dengan penelitian [7] yang mengatakan bahwa pendidikan kesehatan dengan tekhnik bercerita dapat meningkatkan pengetahuan dan sikap anak tentang kesehatan gigi dan mulut. Hamdalah (2013) [8] yang juga menemukan efektivitas pendidikan dengan media buku cerita meskipun tidak diiringi dengan tekhnik bercerita.

\section{KESIMPULAN}

Hasil penelitian dapat dilihat bahwa ada pengaruh pendidikan kesehatan melalui metode story telling terhadap tingkat pengetahuan kebersihan gigi anak usia sekolah di SDN Inpres Kala ( $p=0,037 ; p<0,05)$. Hasil penelitian ini sejalan dengan penelitian Wilda Wahyu F (2013) mengatakan bahwa pendidikan kesehatan dengan tekhnik bercerita dapat meningkatkan pengetahuan dan sikap anak tentang kesehatan gigi dan mulut. Hamdalah (2013) yang juga menemukan efektivitas pendidikan dengan media buku cerita meskipun tidak diiringi dengan tekhnik bercerita.

\section{DAFTAR PUSTAKA}

[1] Lossu dkk, 2015. Ilmu Kedokteran Gigi Gadjah Mada. Yogyakarta : University press

[2] Arora, 2011. Penyebab Utama Karies Gigi, jilid III. Jakarta : Salemba Medica

[3] Ashlee, 2012. Cara Pintar Mendongeng. Jakarta : Mizan.

[4] Mehrdad Ghaffari Targhi (2015) Penggunaan Metode Bercerita Untuk Meningkatkan Minat Baca Anak. Mojokerto

[5] Arikunto. 2010. Prosedur penelitian suatu pendekatan praktik ( edisi revisi ). Jakarta:Rineka cipta
[6] Sugiyono. 2015. Metode Penelitian Pendidikan Pendekatan Kuantitatf, Kualitatif, dan $R$ \& D. Bandung: Alfabeta

[7] Wilda Wahyu F, 2013. Media Bercerita Untuk Meningkatkan Pengetahuan Tentang Perawatan Gigi Dan Mulut . Semarang : Universitas Dipenogoro.

[8] Hamdalah, 2013. Bercerita Untuk Anak Usia Sekolah. Jakarta : Depdiknas 